\title{
Chat Sticker Design as Media Recognition of Character in Instant Messaging Platform
}

\author{
Deni Albar \\ Visual Communication Design \\ Universitas Komputer Indonesia \\ Bandung, Indonesia \\ deni.albar@email.unikom.ac.id
}

\begin{abstract}
According to the goal, this research is applied research with the aim to do something more effective and efficient. The method used is action research, in this research attempt to test a practice to see the real impact of the action. In this case, the delivery of information related to the introduction of Lutung Kasarung characters through the chat sticker design on social media is a form of action that is applied in the daily activities of respondents so that expected to be identified the impact of the action. The results of this study can't be generalized to the general public. Based on the respondents who still need to be studied further, there is a picture of increasing character recognition in the Lutung Kasarung story among teenagers. The conclusion of this research is that a concrete action on the community can have an impact both directly and indirectly; social media can be a medium for the delivery of an action; the introduction of Lutung Kasarung characters can be enhanced through popular media such as the chat sticker design on social media.
\end{abstract}

Keywords - Lutung Kasarung, Design, Stickers, Social Media, Teenager

\section{INTRODUCTION}

This study discusses the design visualization of the sticker conversation about the characters in the story of Lutung Kasarung. Jhon Hasket explained the meaning of design which is quite detailed, 'Design is to design a design to produce a design'. The first is a noun indicating a general concept of a field as a whole; The second is a verb, indicating action or process; The third is also a noun, meaning a concept or proposal; The final use is again a noun, indicating a finished product of some kind [1].

Sticker Chat is an image media that can be animated images and still images used in Instant Messaging applications such as Line, Kakao Talk, WeChat, and so on. Jon Russell explains Sticker is a large-scale emoticon that is mainly use for instant messaging (IM) chat. They are popular among others, especially in Asia, because they help convey emotions, and the visual are more than text blocks [2]. Sticker conversations have become popular media because they are more detailed than just emoticons.

Lutung Kasarung is one of Sundanese folklore originating from West Java, Indonesia. Lutung Kasarung means a lost monkey [3]. Lutung Kasarung tells the story of a god who came from the sky that descended to earth in the form of a monkey. The main characters in this story are Purbasari who is kind and patient, the cunning Purbararang, the wise King Tapak Agung and the good and helpful
Lutung or Guruminda figure. The old King Tapak Agung was about to meditate and surrender his throne to his youngest daughter named Purbasari to become the royal queen. The eldest daughter of the king, Purbararang was jealous and made a sneaky thing to keep his sister Purbasari expelled from the kingdom. Purbasari, who expelled into the forest, met with a powerful Lutung monkey. The Lutung is a god from the sky named Guruminda who descends to earth and gets lost in the forest. Purbasari gets help by a powerful monkey and returns his throne. Monkey also turned into a handsome prince, Guruminda and accompanied Purbasari.

Today's folklore is almost forgotten. In Indonesia Bercerita [4], it is stated that folklore is almost forgotten because it is less popular, even though there are many moral messages, noble intentions and goals from folklore stories. Research on conversation stickers has been widely discussed, such as Gitari Jessica and Elda Franzia research on Line 'Cony Special Edition' character sticker analysis [5], but this research focuses more on finding the visual function of Cony's character stickers on Line applications in communicating between application users. Another research is Muhammad Najib's research on the meaning of emoticon Line Messenger stickers as a medium of interpersonal communication for students from the Faculty of Politics and Sciences of Mulawarman University [6], in this study discussed semiotics from LINE stickers in general. Daniel Kurniawan Salamoon's sticker conversation study entitled "Sticker" LINE, a Symbolic Bridge of Human Interaction Technology in Communication Media [7], describes the mediated communication today. Kate Crowford \& Luke Stark argue that emoji characters both embody and represent the tension between affect as human potential, and as a productive force that capital continually seeks to harness through the management of everyday biopolitics [8]. Willard Van De Bogart and Saovapa Wichadee said The LINE application is often conceived as purely social space; however, they wanted to determine if it could be used for academic purposes [9]. Of all the studies above, no one has specifically discussed the conversation stickers on the folklore of Lutung Kasarung. Of the previous studies on conversation stickers, no one has used action research related to folklore.

\section{METHOD}

The method used in this study is qualitative research using an experimental approach to produce an initial conclusion that can be used to the form of conversation sticker media. In this study there are several stages starting 
from data search, analysis, conclusions to the design of the conversation sticker prototype about the character of the folklore of Lutung Kasarung. The following is an explanation of the method:

The process of data collection in this study carried out with the process of literature study and in-depth interview to have an overview of the knowledge of audiences about Lutung Kasarung folklore characters in adolescents. Respondents in in-depth interviews in this study involved 15 respondents who were conducted in group chat. The research process is carried out within a month, precisely in July 2018. Interviews carried out on adolescents aim to get a picture of their knowledge about the character of the folklore of Lutung Kasarung. So that the findings in this field can be used to media prototypes to be able to accommodate material needs and appropriate technology. The selection of the city of Bandung as a research area was due to the ease of access in research. Bandung is also one of the major cities in Indonesia, which can be a reference for the learning process for other cities especially in West Java.

In the study of target audiences, the characteristics of adolescents can be determined as the main users of the media. Examine the possibility of lifestyle demographics and psychographics of users. The results of this study used to determine media strategies and content, both verbal and visual content. In determining the visualization of the media, data from user audience studies used to suit the tastes and needs of the user. Visualization refers to factual visualization combined with imaginative visualization. The use of factual visualization used to display the real picture of the character conveyed. The use of imaginative images is more used to stimulate teenagers so that they are not boring and in accordance with everyday characters in conversation. Action research action by creating groups consisting of target audiences and pasting sticker media in the group conversation. At the end of the study, the level of knowledge of the audience measured on the characters in the story of Lutung Kasarung.

The chat sticker media about Lutung Kasarung applied to use on the user, so that the results and benefits of the media can illustrate about his knowledge of the Lutung Kasarung folklore. Lutung Kasarung sticker designs can be test in the use of public interests in everyday life and for other social interests in introducing characters in Indonesian folklore. The Lutung Kasarung conversation sticker media taken from the LINE sticker with the Creator is Triwulan.

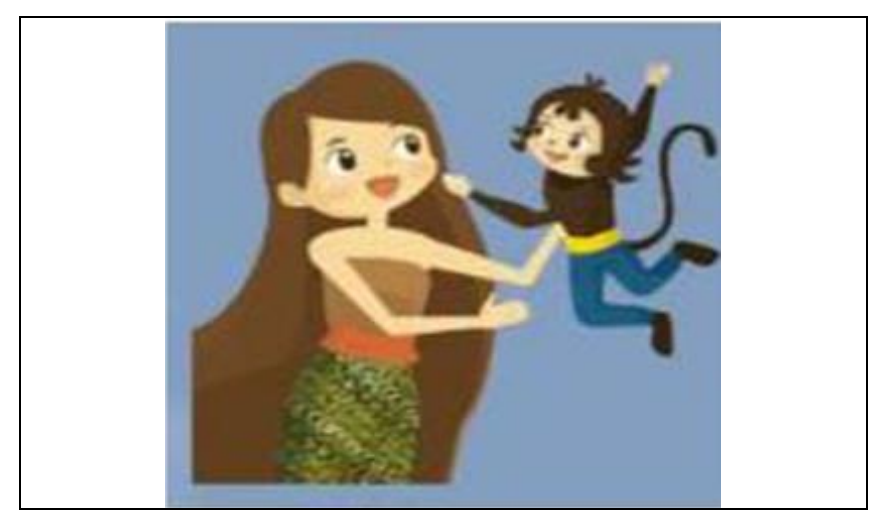

Fig. 1. LINE sticker Purbasari \& Lutung Kasarung
In fig. 1 the characters of Purbasari and Lutung appear with a cheerful and happy impression. This picture shows the characters of Purbasari and Lutung as the protagonists in the story.

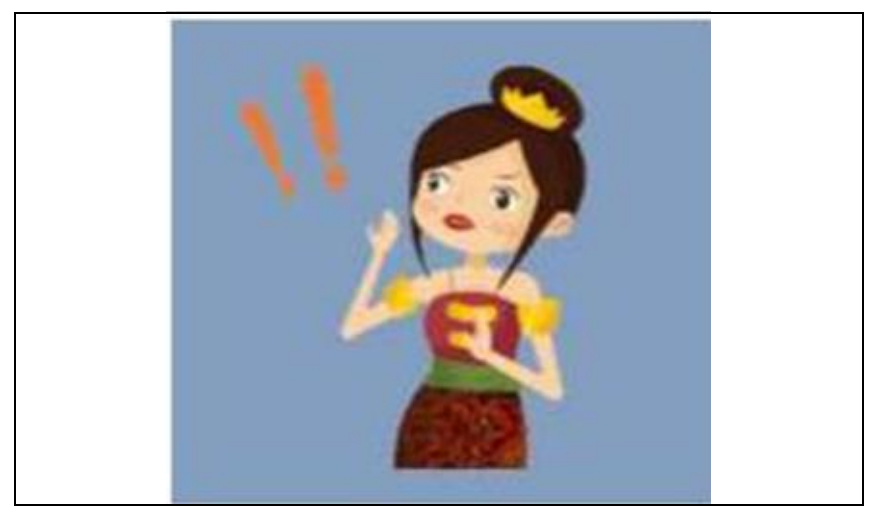

Fig. 2. LINE sticker Purbararang

In fig. 2 displayed the character Purbararang with a surprised facial expression. In the picture above is a surprised expression when Purbasari crowned by King Tapak Agung.

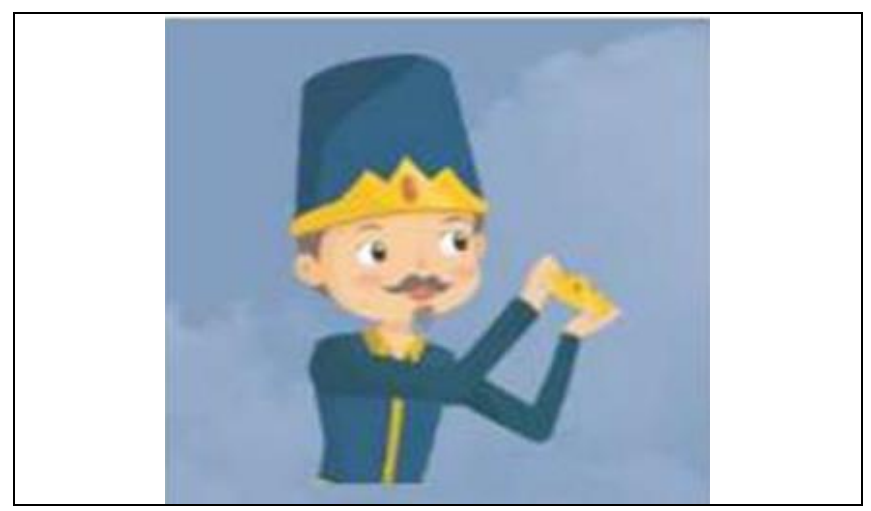

Fig. 3. LINE sticker King Tapak Agung

In fig. 3 displayed the character of the king of Tapak Agung who was radiant and authoritative about giving the crown. The picture above is a scene when the king was about to give a crown when he appointed his youngest daughter, Purbasari, to become the queen of successors to the royal leadership.

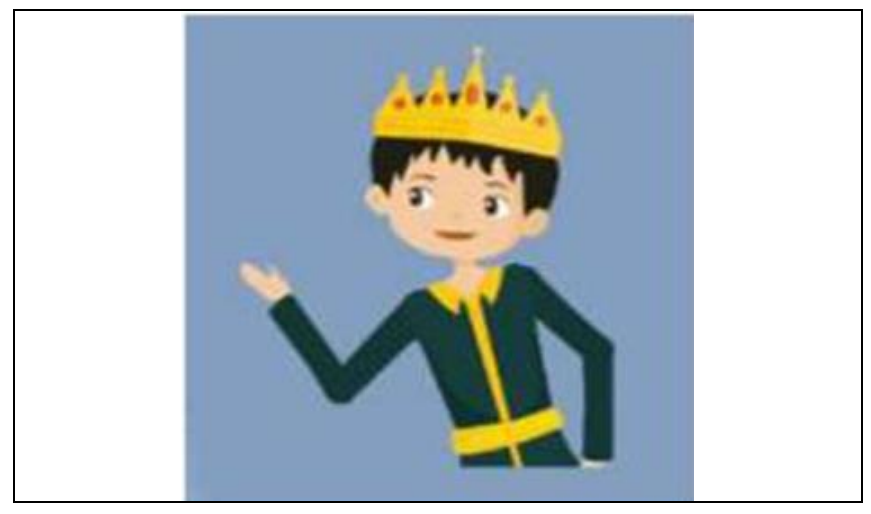

Fig. 4. LINE sticker Guruminda 
In fig. 4 the prince Guruminda's character is shown as a deity from the sky who descends to earth to carry out the journey. Guruminda's character appears with a good and handsome face.

\section{RESULTS}

With the action being tried to be carried out through the conversation group in LINE media with the target audience as a group member, there are the following results: Knowledge of the target audience can be said to have increased, where those who had not known the characters at all, knew better even if they don't know the whole story. The result of the action also shows that the sticker image of a certain figure is able to bring the atmosphere or generalize a person's value or image with the characters in the sticker or vice versa. Member in a group who behaves poorly is often raised by the character Purbararang. Example conversation; "You just... looks like Purbararang." This shows that the characters in the story are already known by member in group. The results in this action research certainly can't be equated in general. Different audiences are very possible to produce different things. The following is a picture related to the results of the action research.

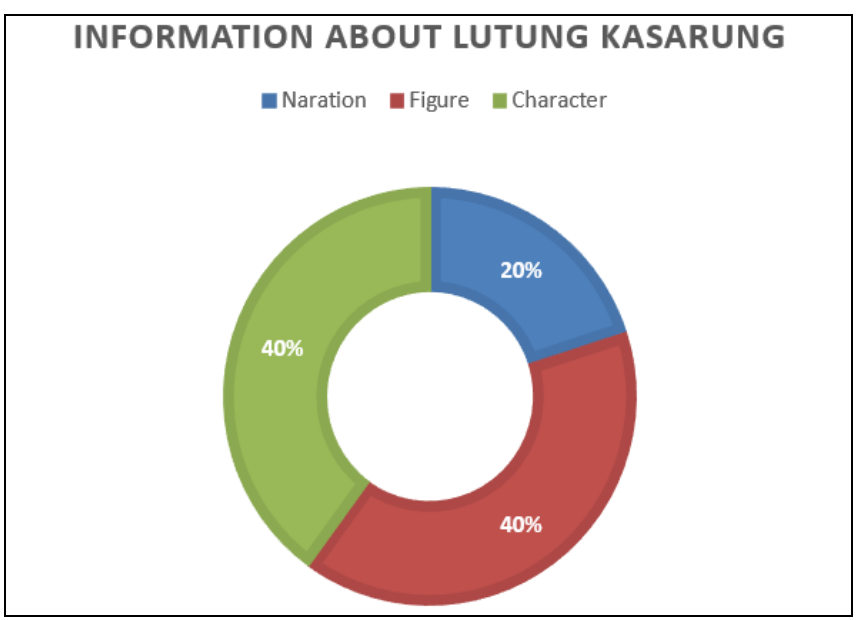

Fig. 5. Chart about information of Lutung Kasarung

In fig. 5 it can be seen that the results of the research on the introduction of character in the story of Lutung Kasarung through the media Sticker conversation can provide knowledge of figure and characters as much as $40 \%$, but in terms of narrative the story is still not optimal, with only $20 \%$.

\section{DISCUSSION}

In this study, it is necessary to discuss design elements in stickers chat. As an object, sticker designs have the same design elements. Design elements consist of shapes + spaces, colors, typography, images and layout. The space in the conversation sticker needs to be adjust to the screen.

RGB color mode is the right color mode for use in conversation sticker designs because it is sure to appear on an electronic screen. The color elements in the Lutung Kasarung sticker design use softly color and not too contrast. The use of soft and not too contrasting colors can make the user's eyes not get tired quickly. Contrast colors that appear simultaneously can affect the eyes. In Samara
[10], simultaneous contrast is able to create optical illusions and trick color changes. This if raised continuously can make the eyes work hard.

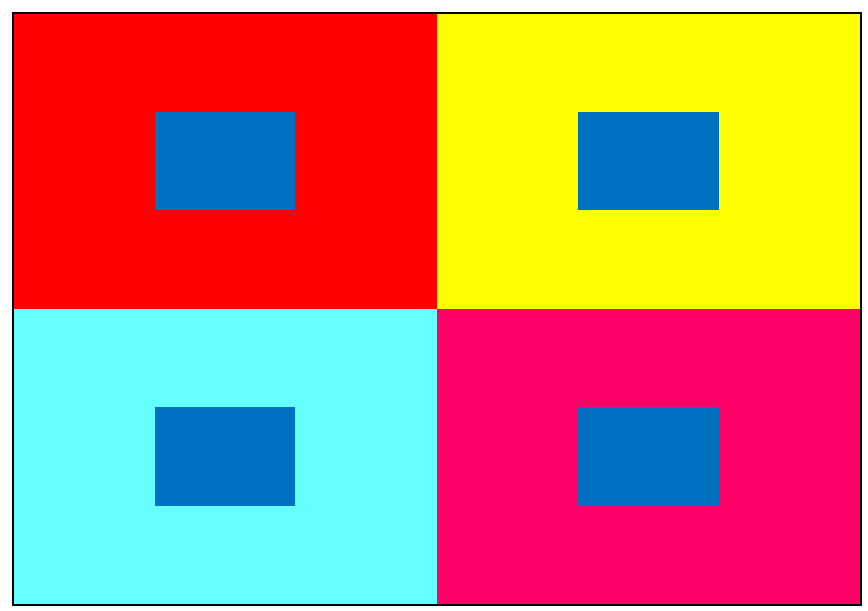

Fig. 6. Contrast Simultan Color

The typography in the conversation sticker are able to help the audience to understand more better the purpose of the sticker. Sticker conversations don't always just rely on face emotions or character gestures. The existence of typography characters in stickers can help better the message to be convey, so that it can be said that the use of letters in stickers increases the achievement of messages. In the Lutung Kasarung sticker created by Triwulan in LINE, it is not support by typography, so that ordinary people who do not know anything about the story of Lutung Kasarung are more difficult in understanding the message in the sticker.

The following image of its style can certainly affect the audience. Adolescent audiences over time will certainly be more accustomed to images that often seen in their daily lives. A person who is unfamiliar with the world of abstract painting will certainly have difficulty to understand about it, its form can make the lay audience feel not part of him. So in the use of stickers chat, the images that are usually present in their daily life are more easily accepted. Images that match the teen theme are certainly more appropriate when used in the Lutung Kasarung conversation sticker.

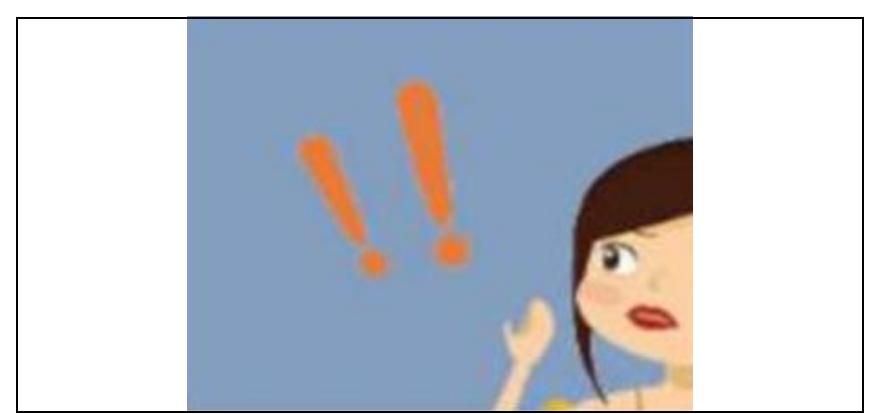

Fig. 7. Typo Element on Chat Sticker

The use of layout elements in the sticker can affect the message received. The inappropriate layout position can interfere with the purpose to be conveyed. The position of 
the image facing left or right can confuse the direction of the other person. The position of the character image facing the user is a neutral position, so that when placed on the left or right will produce an undisturbed message.

\section{CONCLUSION}

In this study, it can be concluded that the conversation stickers about characters can act as a medium that helps character recognition. A person's character can be imaged through a conversation sticker. If a sticker with a description of certain characters is routinely used, consciously or unconsciously, the audience or the other person can be affected. Colors in the conversation sticker should not use colors that have high temperatures and are displayed simultaneously, this is able to make optical illusions even interfere with the meaning of the image. The letter elements in the conversation sticker can help facilitate the delivery of the intended message. The use of picture styles in the conversation sticker should be adjusted to the target audience so that it can be well received by the audience. A person's character that will be conveyed to two different groups of audiences, can be delivered with two different images according to their respective audiences.

\section{ACKNOWLEDGMENT}

The author wishes to thank the organizers who have worked hard and made it easy for the publication and dissemination of this research to be accepted. The author also expressed his gratitude to the Unikom institution which has encouraged the author to continue to develop and make this research. Thank you to all parties who have been involved in this research, because without all help, this research will not succeed.

\section{REFERENCES}

[1] J. Hasket, Design: a very short introduction. New York: Oxford University Press Inc, 2002, pp. 3-4.
[2] J. Russell, "What are stickers and why are people buying them?," thenextweb.com, July. 12, 2013. [Online]. Available: https://thenextweb.com/asia/2013/07/12/stickers/ [Accessed: August. 01, 2018]

[3] “Cerita rakyat Indonesia: Lutung kasarung," Feb, 05. 2015. [Online] Available: https://dongengceritarakyat.com/cerita-rakyat-indonesialutung;kasarung/ [Accessed: August. 01, 2018].

[4] 'Melestarikan cerita-cerita yang nyaris terlupakan,' June. 07, 2017. [Online]. Available: https://www.koran-jakarta.com/melestarikancerita-cerita-yang-nyaris-terlupakan/ [Accessed: August. 01, 2018].

[5] G. Jessica and E. Franzia, "The analysis of line sticker character 'Cony Special Edition'," Jurnal Humaniora, vol.8, no.3, pp. 291-301, 2017. [Online]. Available: https://journal.binus.ac.id/index.php/Humaniora/article/download/390 4/3204 [Accessed: August. 01, 2018].

[6] M. Najib, "Pemaknaan stiker emoticon Line Messenger sebagai media komunikasi interpersonal mahasiswa Fisipol Universitas Mulawarman," eJournal Ilmu Komunikasi, vol.2, no.3, pp. 421-430, 2014. [Online]. Available: https://ejournal.ilkom.fisipunmul.ac.id/site/wp-

content/uploads/2014/09/Pemaknaan\%20Sticker\%20Emoticon\%20LI NE\%20Messenger\%20(Muhammad\%20Najib) \%20(09-16-14-05-0308).pdf [Accessed: August. 01, 2018].

[7] D. K. Salamoon, “'Sticker' LINE, Sebuah Jembatan Simbolik Teknologi Interaksi Manusia dalam Media Komunikasi,” Jurnal Nirmana, vol.16, No.01, pp. 12-17, 2016. [Online]. Available: http://nirmana.petra.ac.id/index.php/dkv/article/view/19856/19065 [Accessed: August. 01, 2018].

[8] K.Crowrford and L. Stark, "The Conservatism of Emoji: Work, Affect, and Communication," Sage Journals, Social Media+Society, July-December, 2015: I-II. [Online]. Available: http://journals.sagepub.com/doi/pdf/10.1177/2056305115604853 [Accessed: August. 01, 2018].

[9] W.V.De Bogart and S. Wichadee, "Exploring Students' Intention to Use LINE for Academic Purposes Based on Technology Acceptance Model,” IRRODL, Vol.16, No.03, 2015. [Online]. Available:

http://www.irrodl.org/index.php/irrodl/article/view/1894/3344 [Accessed: August. 01, 2018].

[10] T. Samara, Design elements: a graphic style manual. Massachusetts: Rockport Publishers, 2007, pp. 94-95. 